\title{
SHORT-TERM TOXICITY TEST OF SINGALAWANG EXTRACT ON MALE WHITE RATS KIDNEY NECROSIS
}

\author{
Ardy Hamonangan Naibaho', Arifa Mustika ${ }^{2}$, Anny Setijo Rahaju ${ }^{3}$ \\ ${ }^{1}$ Medical Doctor Program, ${ }^{2}$ Department of Medical Pharmacology, \\ ${ }^{3}$ Department of Anatomic Pathology, Faculty of Medicine, \\ Universitas Airlangga, Surabaya
}

\begin{abstract}
ABSTRAK
Daun Singawalang digunakan masyarakat sebagai obat tradisional penderita pneumonia akibat penyakit TBC. Upaya penelitian bidang botani maupun farmakologi terhadap daun singawalang (Petiveria alliaceae) sudah banyak dilakukan. Beberapa penelitian bertujuan mengetahui khasiat daun tersebut sudah dilakukan, namun penelitian untuk mengetahui keamanan penggunaannya masih jarang. Penelitian ini bertujuan untuk mengetahui toksisitas jangka pendek ekstrak daun Singalawang. Penelitian ini merupakan jenis laboratorium eksperimental dengan rancangan penelitian the post - test only control group design. Metode pengambilan sampel ialah simple random sampling, menggunakan sampel 32 ekor mencit (Mus musculus) jantan sebagai hewan coba dengan berat badan rata-rata 20 gram dan berumur kurang lebih 2 bulan. Hewan percobaan dibagi ke dalam 4 (empat) kelompok, masingmasing kelompok terdiri dari 8 (delapan) ekor mencit yaitu, kelompok kontrol (P0) mendapat aquadest sebagai pelarut bahan. Kelompok perlakuan 1 (P1) mendapatkan ekstrak etanol daun singawalang (Petiveria alliaceae) dosis rendah yaitu $90 \mathrm{mg} / \mathrm{kgbb}$. Kelompok perlakuan 2 (P2) mendapatkan ekstrak etanol daun singawalang (Petiveria alliaceae) dosis sedang yaitu $180 \mathrm{mg} / \mathrm{kgbb}$. Kelompok perlakuan 3 (P3) mendapatkan ekstrak etanol daun singawalang (Petiveria alliaceae) dosis tinggi yaitu 360mg/kgbb. Ekstrak etanol diberikan secara peroral menggunakan sonde sehari sekali selama 30 hari. Hasil penelitian ini menunjukkan bahwa ekstrak etanol daun singawalang (Petiveria alliaceae) ini tidak memberikan efek nekrosis secara sub-akut pada ginjal mencit jantan putih (Mus musculus) pada dosis $90 \mathrm{mg} / \mathrm{kgbb}, 180 \mathrm{mg} / \mathrm{kgbb}$, dan $360 \mathrm{mg} / \mathrm{bb}$. (FMI 2016;52:62-65)
\end{abstract}

Kata kunci: ekstrak singawalang, nekrosis, ginjal

\begin{abstract}
Singawalang leaf is used as a traditional medicine by the communities suffering from pneumonia due to TB disease. However, experiments to explain it's toxicity are few. Therefore, this study was conducted to disclose it's toxicity. This was an experimental laboratory study using post-test only control group design. The sampling method was simple random sampling. The animals were randomly divided into 4 (four) groups, each group consisted of 8 (eight) mice, the control group (P0) received distilled water as a solvent material. Treatment group 1 (Pl) obtained ethanol extract of singawalang (Petiveria alliaceae) in low doses of $90 \mathrm{mg} / \mathrm{kg} b \mathrm{w}$. Treatment group 2 (P2) obtained ethanol extract of singawalang (Petiveria alliaceae) in medium doses of $180 \mathrm{mg} / \mathrm{kgbw}$. Treatment group 3 (P3) obtained ethanol extract of singawalang (Petiveria alliaceae) in high doses of $360 \mathrm{mg} / \mathrm{kgbw}$. Th extracts were given with sonde once a day for 30 days. Results showed that the leaf ethanol extract singawalang (Petiveria alliaceae) does not induce sub-acute necrosis effects on kidney of male white mice (Mus musculus) in doses $90 \mathrm{mg} / \mathrm{kgbw}, 180 \mathrm{mg} / \mathrm{kgbw}$, and $360 \mathrm{mg} / \mathrm{kgbw}$. (FMI 2016;52:62-65)
\end{abstract}

Keywords: Singawalang extract, necrosis, kidney

Correspondence: Arifa Mustika, Department of Medical Pharmacology, Faculty of Medicine, Universitas Airlangga, Jalan Mayjen Prof dr Moestopo 47, Surabaya 60131, Indonesia.

\section{INTRODUCTION}

Traditional medicine is generally consumed by Indonesian people for prevention and treatment of disease. This phenomenon occurs because traditional medicines easily available and relatively cheap. It is also supported by the fact that Indonesian population are distributed largely in villages and lack of health care facilities are increasingly making traditional medicine very widely consumed (Sarman 2008).
Indonesia is famous with a variety of traditional medicinal plants. One of them is the leaf singawalang (Petiveria alliaceae). This plant-shaped bush has ducked shape and its height may reach $1 \mathrm{~m}$. It has long leaves of 6-19 cm long, pointed, and sharp. First time it entered Indonesia through India and is most prevalent in tropical areas. This plant belongs to the family Phytolacceae (Sarman 2008).

Leaves Singawalang (Petiveria alliaceae) is widely used by the common people as a traditional medicine. 
Empirically, in Indonesia leaves singawalang (Petiveria alliaceae) used by the people as a traditional medicine for pneumonia due to tuberculosis (TB). In tropical America, leaves singawalang (Petiveria alliaceae) is used as a cough medicine. By locals, this plant is also used as a diuretic, expectorant and antispasmodic (Sarman 2008).

However, validatation of the efficacy of leaves singawalang (Petiveria alliaceae) requires scientific data. Research efforts have been undertaken in the field of botany and pharmacology on the leaf singawalang (Petiveria alliaceae). In addition, to determine the efficacy of the leaf, study on its safety use is needed. However, acute toxicity tests have been done on the leaves singawalang (Petiveria alliaceae) to test the toxic effects, so it is necessary to conduct sub-acute toxicity tests singawalang leaf (Petiveria alliaceae) to test the level of safety in much longer time.

This study aims to determine the sub-acute effect that of the leaf extract singawalang (Petiveria alliaceae). Each chemicals and drugs must contain xenobiotic materials (materials that are not recognized by the body). This material needs to be tested for its safety level effects of toxicity, therefore it is necessary to perform sub-acute toxicity tests singawalang leaf extract (Petiveria alliaceae) in the kidney of male white mice (Mus musculus) before it is widely applied in humans.

\section{MATERIALS AND METHODS}

This study was a laboratory experimental study using post-test only group design. The study was conducted in the Department of Pharmacology and Biochemistry of the Faculty of Medicine, Universitas Airlangga. The study was conducted from September 2012 to March 2013.

\section{Laboratory procedures}

Experimental animals in this study were male white mice (Mus musculus), aged 2-3 months with body weight ranging from 20-30 grams, physically healthy (hairy slick, shiny and clean, not thin, no mucus or pus from the nose, eyes, ears and tail were all normal). Sampling method used simple random sampling where the sample members were randomly determined. The whole animals were adjusted to the environment for 2 weeks and their condition was maintained. Feed and and water were given ad libitum. Mice were placed in a cage with chaff, each containing 8 mice.

Leaves Singawalang was taken of Materia Medica Batu and has been determined in advance. Extraction of the content of Petiveria alliaceae was done by maceration using absolute ethanol. The extracted plants were those whose leaves were picked and dried with aerated. After drying, they were crushed into powder, then the powder weighed of 100 grams and soaked with absolute ethanol as much as twice of powder's volume and then shaken, being kept for 24 hours in a sealed container, and then filtered. The residue of the leaves was soaked with absolute ethanol twice of its volume. The procedure was repeated for four times. The extract obtained was evaporated with a rotary evaporator until the ethanol not dripped anymore, and then stored in exticator until constant weight is obtained. The dose was given to the group in low, medium and high doses, as determined by taking into account the recommended dose in humans and dose conversion from humans to mice.

Based on previous studies, the compound was also stimulates the activity of white blood (phagocytes) in the system of spleen, lymph granules, spine, and liver (reticuloendothelial system) in killing germs and other foreign elements. Instead, it was not active as an antitumor. Results were obtained from trials with a dose of $360 \mathrm{mg} / \mathrm{kg}$ to $100 \mathrm{rats}$, in which in the end half of the mice had died (LD50) (Sarman 2008).

This study used 32 male mice (Mus musculus) as experimental animals with an average weight of 20-30 grams and aged less than 2 months old. The mice were fasted for 18 hours before being treated to avoid feed but drink still be given. Body weight of each mouse was weighed using animal scale.

Experimental animals were randomly divided into four groups, each consisting 8 mice, namely: 1) Control group (P0) receiving distilled water as a solvent material, 2) treatment group 1 (P1) obtained extracts of leaves singawalang (Petiveria alliaceae) in low dose of $90 \mathrm{mg} / \mathrm{kg}$, 3) treatment group 2 (P2) obtained leaf extract singawalang (Petiveria alliaceae) in moderate doses of $180 \mathrm{mg} / \mathrm{kg}$, 4) treatment group 3 (P3) obtained leaf extract singawalang (Petiveria alliaceae) in high doses of $360 \mathrm{mg} / \mathrm{kg}$

Number of replicates (n) in each group was minimally 7 animals, but in order to simplify the calculation, the samples used in each group was 8 mice, such that the number of mice required was minimally 32 . All mice were weighed at baseline and at the end of study.

At the beginning of the study we conducted initial examination as a control. Observation was done for 24 hours, to determine the presence and number of animal deaths during that period. Then it was continued for 30 days with the extract per day using oral sonde. If during the study no mice were dead, then immediately autopsy 
and macro- and microscopic examination of the kidney were done.

Histological changes due to quantitative tubular necrosis can be calculated from the number of tubules that showed cell necrosis, loss of brush border, cast formation, and tubule dilatation. Assessment conducted were: a score of 0 in the absence of necrosis; 1 score if renal tubular necrosis $<10 \% ; 2$ if renal tubular necrosis $11-25 \%$; 3 if renal tubular necrosis $26-45 \%$; 4 if renal tubular necrosis $46-75 \%$; and 5 if renal tubular necrosis $76 \%$. Observations were carried out in at least 10 visual fields with 100 times magnification (Lien et al 2006).

\section{RESULTS}

Table 1. Results of sub-acute toxicity of the leaves singawalang (Petiveria alliaceae) in the kidney of male white mice (Mus musculus)

\begin{tabular}{ccccc}
\hline $\begin{array}{c}\text { Replication } \\
\text { groups }\end{array}$ & Control & P1 & P2 & P3 \\
\hline 1 & 0 & 0 & 0 & 0 \\
2 & 0 & 0 & 0 & 0 \\
3 & 0 & 0 & 0 & 0 \\
4 & 0 & 0 & 0 & 0 \\
5 & 0 & 0 & 0 & 0 \\
6 & 0 & 0 & 0 & 0 \\
7 & 0 & 0 & 0 & 0 \\
8 & 5 & 0 & 0 & 0 \\
\hline
\end{tabular}

The observations in the control group (P0) receiving aquadest $1 \mathrm{ml} /$ day for 30 days did not cause kidney necrosis. Kidney necrosis on 8 th replication was not caused by exposure to singawalang leaf extract. Murine renal tubular necrosis was found in 8th experimental animal of $\geq 76 \%$. The mouse was the one that was found dead on the morning of the 11th day, so it was not the subject of the experimental animals that was taken into account. Observations in group 1 (P1) singawalang leaf extract (Petiveria alliaceae) $90 \mathrm{mg} / \mathrm{kg}$ in mice $(0.269 \mathrm{~g} \%) 1 \mathrm{ml} /$ day for 30 days did not cause kidney necrosis on the experimental animals.

Observations in group $2(\mathrm{P} 2)$ receiving singawalang leaf extract (Petiveria alliaceae) $180 \mathrm{mg} / \mathrm{kg}$ in mice $(0.528 \mathrm{~g} \%) 1 \mathrm{ml} /$ day for 30 days did not cause kidney necrosis on experimental animals. The observation of group 3 (P3) Award singawalang leaf extract (Petiveria alliaceae) $360 \mathrm{mg} / \mathrm{kg}$ in mice $(1.056 \mathrm{~g} \%) 1 \mathrm{ml} /$ day for 30 days also did not cause kidney necrosis on the experimental animals.
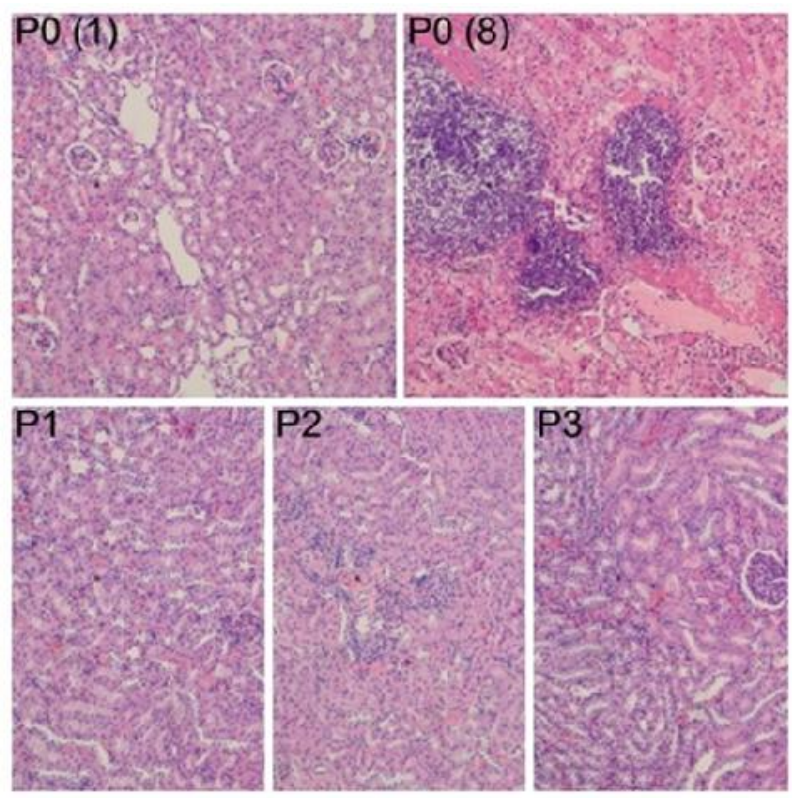

Fig. 1. Results of sub-acute toxicity test of the leaves singawalang (Petiveria alliaceae) in the kidney of male white mice (Mus musculus)

Results of short-term (sub-acute) toxicity tests on singawalang (Petiveria alliaceae) leaf extract on necrosis of the kidneys of male white mice (Mus musculus) for 30 days showed that the leaf extract of singawalang (Petiveria alliaceae) from Batu, East Java, showed that it did not induce renal necrosis in doses of $90 \mathrm{mg} / \mathrm{kgbw}, 180 \mathrm{mg} / \mathrm{kgbw}$ and $360 \mathrm{mg} / \mathrm{kgbw}$.

\section{DISCUSSION}

Short-term toxicity tests on extract of singa-walang (Petiveria alliaceae) white to the kidney of male white mice (Mus musculus) revealed not to cause necrosis of the kidneys. The results of this study were similar to those found by Zakaria in 2010, which proved that the ethanol extract of the leaves do not have acute toxicity.

Toxic effect can be reversible and irreversible. Toxic effect can be reversed when the body is exposed to low levels or for a short time, while irreversible effects can be generated from exposure to higher levels or for a long time ( $\mathrm{Lu} \mathrm{1985).} \mathrm{Therefore,} \mathrm{in} \mathrm{elevated} \mathrm{level} \mathrm{and}$ extended test time in chronic toxicity test irreversible toxic effects might be generated, which in this regard was necrosis. 
Functional effects usually reversible, whereas the morphological effects usually irreversible. Several studies have been conducted to find functional changes that can be identified in advance, or can be detected in animals in lower doses than the dose that causes morphological changes. Evidence gathered from liver and kidney tests seemed not supporting this notion. However, recent discoveries showed that functional test may be more sensitive. In addition, functional testing is valuable for the continued monitoring of toxic effects on target organs in the long-term studies in animals and humans ( $\mathrm{Lu} \mathrm{1985).} \mathrm{The} \mathrm{present} \mathrm{study} \mathrm{does} \mathrm{not} \mathrm{address}$ the toxicity of ethanol extract on organ function that needed further research.

\section{CONCLUSION}

The ethanol extract of leaves singawalang does not cause death if exposed once and the reaction is awaited for 24 hours in doses of $90 \mathrm{mg} / \mathrm{kg} \mathrm{bw}, 180 \mathrm{mg} / \mathrm{kg} \mathrm{bw}$, $360 \mathrm{mg} / \mathrm{kg}$ bw. This proves that the extract of singawalang leaves does not have acute toxicity. The result of short-term toxicity test (sub-acute) of singawalang (Petiveria alliaceae) leaf extract on kidney necrosis of male white mice (Mus musculus) for 30 days showed that singawalang (Petiveria alliaceae) the leaf extract is not nephrotoxic.

\section{REFERENCES}

Lien Y-HH, Yong KC, Cho S, Igarashi S, Lai LW (2006). S1P ${ }_{1}$-Selective Agonist, $\mathrm{SEW}_{2871}$, ameliorates ischemic acute renal failure. Official Journal of The International Society of Nephrology 69, 1601-1608

Lu FC (1985). Basic Toxicology: Fundamentals, Target Organs, and Risk Assesment, Washington DC, Hemisphere Publishing Corporation, p 46-65

Sarman (2008). Singawalang, si tangguh melawan TBC. Available from http:/omnilogos.blogspot.com/2008/ 12/singawalang-si-tangguh-melawan-tbc.html. Accessed July 25, 2012

Zakaria (2010). Uji Toksisitas Akut Daun Singawalang pada Mencit Putih Jantan. Research Report, Universitas Airlangga, Surabaya. 